\title{
China's Maritime Silk Road Initiative: A quest for sea power
}

\author{
Lungani Hlongwa ${ }^{l}$ \\ National Chiao Tung University, Hsinchu, Taiwan
}

\begin{abstract}
Much has been written about China's deep ambitions as the country moves towards great power status. The Maritime Silk Road Initiative (MSRI) is just one example of how China is flexing its muscles, and if history is to be believed, there is a strong correlation between maritime success and national economic prosperity. The study, on which this article reports, examined China's MSRI through the lens of sea power theory. It was argued that the New Silk Road, which will most likely be backed by a modern blue-water navy, could represent a new era of maritime supremacy. However, to see the MSRI as a pursuit of sea power requires an understanding of how maritime logistics functions as power. The seamless movement of goods across the ocean is at the heart of the MSRI. Therefore, the research question that was pursued related to how maritime logistics functions as a tool for power projection. Although sea power theory recognises merchant shipping as a core element of sea power, it was further argued that scholarly work in critical logistics and mobility studies could enhance our understanding of logistical power. The study therefore aimed to conceptualise the MSRI through the lens of sea power by highlighting maritime logistics as a strategic conduit for power projection.
\end{abstract}

Keywords: sea power, tianxia, logistics, People's Liberation Army Navy, Maritime Silk Road Initiative

\section{Introduction}

The Maritime Silk Road Initiative (MSRI) and its cousin project, the Silk Road Economic Belt (SREB), were announced separately in 2013 by Chinese president Xi Jinping. ${ }^{2}$ Together, the two projects are commonly referred to as the "One Belt, One Road" (OBOR) or the "Belt and Road Initiative" (BRI). On land, the SREB aims to bring together China, Central Asia, Russia and Europe by building a thoroughfare or land bridge across the Eurasian landmass. ${ }^{3}$ The MSRI is, at least in the imagination, based on the ancient Silk Road that stretched from Fuzhou (a coastal city in Fujian, China) and then went to Southeast Asia through the South China Sea (SCS). From Southeast Asia, the route went through the Malacca Strait into the Indian Ocean, and then via the Mediterranean to Europe. ${ }^{4}$ Historians agree that silk was only one of the valuable items that were traded along the ancient Silk Road. ${ }^{5}$ According to Andrea, ideas and culture were the historically more significant "commodities" that were traded along these routes. ${ }^{6}$ Many scholars analyse the SREB and MSRI concurrently. However, 
Blanchard and Flint caution that, given the many differences in political, economic and social aspects, the two initiatives are distinct projects and should be analysed separately. ${ }^{7}$

The MSRI has received much attention since it was announced in 2013. On the one hand, some view the initiative purely as a win-win approach to economic development for China and its partners. For example, Koboević et al. see the initiative as "promoting shared development and prosperity, peace, and friendship, through enhancing mutual understanding, trust, and exchanges". ${ }^{8}$ They go as far as to say that the initiative has no military or political objectives. On the other hand, some are more sceptical of China's approach to building the MSRI. Thorne and Spevack argue that there is a mismatch between what Beijing wants the world to believe about the MSRI and Beijing's harboured ambitions. ${ }^{9}$ They point out that Chinese analysts routinely prioritise China's strategic interests in their discussions on the MSRI. Ameyaw-Brobbey concludes that China's approach to building the MSRI is questionable. ${ }^{10}$ Many developing countries who take up Chinese loans for infrastructural development are left indebted to China. This situation, according to Ameyaw-Brobbey, increases global security problems, among other issues.

Although such opposing views on the MSRI are undoubtedly provocative, the literature on the subject so far has mostly been descriptive and shunned the use of academic concepts from geopolitics and international relations (IR). ${ }^{11}$ Xin Zhang, who views the MSRI from the perspective of world systems theory, is among the few scholars who apply theoretical lenses in analysing the MSRI. ${ }^{12}$ Some scholars also focus on the local implications of the MSRI in various locations. Styan, for example, examined the implications of the MSRI for Djibouti. ${ }^{13}$ Karim explored the opportunities and challenges of the MSRI for the Bay of Bengal region. ${ }^{14}$ Lim discusses the place of Africa in China's MSRI. ${ }^{15}$ Indeed, such work contributes much to understanding the local implications of the MSRI. However, neither opposing nor locally specific scholarly work on the MSRI can help us navigate the complexity of the initiative. Using a theoretical lens could therefore enhance our understanding of the MSRI from a certain perspective. Like maps, theoretical lenses can help us simplify a complicated world. ${ }^{16}$ Olivier et al. remind us that theoretical lenses in IR could help explain the social dynamics of the world in which we live. ${ }^{17}$ In this article, the author proposes sea power theory as a theoretical lens for analysing the MSRI. The author argues that sea power theory has much explanatory power, which can be further increased by scholarly work in critical logistics and mobility studies.

In 1889, Mahan wrote that whoever dominates the sea with maritime trade and naval power, would have a significant influence in the world. ${ }^{18}$ His theory on sea power emphasised, among other things, the intricate connection between maritime trade and naval power. Mahan's ideas are not foreign in China. His work is widely read by both promoters and sceptics of sea power. ${ }^{19}$ For a long time in China, there was a debate about whether China should pursue sea power. ${ }^{20}$ However, for China, turning to the sea is no longer an option but a matter of survival. Xin Zhang points out that Chinese capitalism is in crisis and in need of a "spatial fix". ${ }^{21}$ With thirty years of economic growth, China now finds itself with huge surpluses with no local market to absorb them 
all. Xin Zhang argues that the MSRI is a way for China to gain access to foreign markets and global resources. Therefore, the sea, as the road that leads to everywhere, is vital for China's 'going out' strategy, and the MSRI is a big part of it. The debate, therefore, is no longer about whether China should pursue sea power, but rather about the direction of its development. ${ }^{22}$

Zhang Wei contends that for China, sea power cannot be pursued in Mahanian fashion, which hinges on the decisiveness of sea battles. ${ }^{23} \mathrm{He}$ points out that we live in a globalised world where cooperative development is mainstream. For this reason, China has been studying the failures and successes of former great powers in the West, among which is Imperial Germany under Otto von Bismarck. According to Holmes and Yoshihara, Otto von Bismarck is a revered figure in China for adopting a benign and low-profile grand strategy for the development of Imperial Germany. ${ }^{24}$ The Bismarckian model of grand strategy is one that promotes cooperative economic growth while allaying suspicion among neighbouring states. ${ }^{25}$ China, according to Holmes and Yoshihara, strives to replicate the Bismarckian model of grand strategy. ${ }^{26}$ The win-win stance towards the MSRI can therefore be seen as China's ambition to rise peacefully within the international system. As will be argued in this article, sea power for China will not be centred on the navy. Rather, it will revolve around sea-based hyperconnectivity mainly through the MSRI. As Cowen clarifies, China might be better understood as a logistical empire. ${ }^{27}$ This, however, does not mean that the navy has become irrelevant. Indeed, as will be discussed later in this article, the conditions for trade - to move goods across the ocean - must be protected.

This study, on which this article reports, aimed to conceptualise the MSRI through the lens of sea power theory by highlighting maritime logistics as a strategic conduit for power projection. To further our understanding of how maritime logistics functions as power, the author turns to the disciplines of critical logistics and mobility studies where scholars are investigating logistics as a logic of capitalism. It is argued that the scholarship in these disciplines could enhance the explanatory strength of sea power theory as far as the MSRI is concerned. In terms of strategy, the naval side of sea power is well developed. However, maritime logistics, as the other side of sea power, still lacks behind in terms of theorisation. For this reason, maritime logistics as sea power might need further elaboration beyond traditional sea power theory.

\section{The twenty-first century maritime Silk Road}

The imagination of the twenty-first century Silk Road is based on the ancient trade routes formally established during the Han dynasty in China (206 BC-AD 220). ${ }^{28}$ The name itself derives from the primary commodity exported by the Chinese, which was silk. Due to the huge surpluses of the legendary Han dynasty, trade routes were established to connect China with the West and the South, as China sought foreign markets for its products. Today, China wants the same expansion to the West and the South as its surpluses grow again. ${ }^{29}$ Proponents of the twenty-first century Silk Road emphasise connectivity through trade, investment opportunities and infrastructural development. The Maritime Silk Road (MSR) covers dozens of countries with a total 
population of three billion people. ${ }^{30}$ However, Stenberg et al. remind us that creating infrastructure requires residents, communities, governments and physical embodiments of the nation-state. ${ }^{31}$ Given this situation, the MSRI faces numerous geopolitical challenges ahead. China has already approached all countries along the sea routes seeking their partnership. ${ }^{32}$

To its partners, China presents the MSRI as a mutually beneficial and collective approach to economic development. While China seeks to boost its growth through foreign markets, the idea is that member states will accelerate economic development through the construction of much-needed infrastructure. ${ }^{33}$ Africa has also been included in the overall BRI. As far as the MSRI is concerned, infrastructural development to be undertaken in Africa includes the development of deep-water ports in African cities such as Bizerte (Tunisia), Dakar (Senegal), Dar es Salaam (Tanzania), Djibouti City (Djibouti), Libreville (Gabon), Maputo (Mozambique) and Tema (Ghana). ${ }^{34}$ These ports will connect with the MSR as they are meant to serve large commercial ships coming from Asia. According to Aneja, these ships will be laden with food and industrial products from Asia and will return with raw materials from Africa. ${ }^{35}$ Brautigam believes that China's exchange of infrastructure for Africa's natural resources is based on China's own positive experience when China exchanged its oil for Japanese industrial technology in the 1970s. ${ }^{36}$ It was the Japanese technology - argues Brautigam - that enabled China to achieve economic growth during the 1980s. So far, Africa's reliance on the exportation of natural resources has proved to be tragic for the continent. Most mineral-rich countries in Africa have not been able to achieve satisfactory economic growth from mining revenues. ${ }^{37}$ On the contrary, most countries have performed very poorly, giving rise to what is known as "the resource curse." 38 The resource curse hypothesis holds that countries rich in mineral resources exhibit poor economic growth compared to resource-poor countries. ${ }^{39}$ The role of Africa in the MSRI indeed requires a much-needed discussion.

Djibouti is a good example of China's investments in Africa. Since 2013, China has been investing heavily in ports and railways in Djibouti. ${ }^{40}$ For China, the small Red Sea state is key to securing Chinese trade and building a naval presence in the region. ${ }^{41}$ In Djibouti, home to China's first overseas naval base, the connection between the MSRI and the navy cannot be missed. Like the MSRI, the proposal to establish the military facility in Djibouti was also put forward in 2013. ${ }^{42}$ The timing was significant because one of the missions of the naval base is to secure the BRI. ${ }^{43}$ Odgaard points out that in East Africa, China is simultaneously carrying out the mandate of the United Nations in peacekeeping operations, while pursuing its own objectives related to the BRI. ${ }^{44}$ Although the Chinese naval base in Djibouti is justified as a logistics support station, the facility demonstrates impeccable military capabilities, such as the capacity to accommodate more than a brigade-strength force, a unique four-layered security fence, and the capacity to handle a dozen helicopters. ${ }^{45}$ This goes against the view by some that the MSRI has no military objectives. Even today, where maritime commerce flows relatively unmolested, the conditions for trade must be protected. ${ }^{46}$ 
In 2014, President Xi paid a visit to the Maldives where a memorandum of understanding (MOU) was signed to increase trade and tourism in the country. The MOU also meant that the Maldives were now official members of the MSRI ${ }^{47}$ For the MSRI to succeed, China also has to win the trust of wary neighbours, such as Vietnam, Russia and India. ${ }^{48}$ According to Khurana, China-India relations will be a crucial determinant of the geopolitical, economic and security environment of Asia. Lately, both countries have emerged as significant economies with growing maritime interests. Therefore, the success of the MSRI also hinges on good relations between China and India, especially on matters concerning the maritime domain. ${ }^{49}$ China, therefore, has good reasons why it should seek to emulate the Bismarckian model of grand strategy. Whether or not that is possible, is another matter.

Within the academic community, the views on the motivating factors of the BRI vary greatly. Sternberg et al. ${ }^{50}$ made a collection of some of these views, among which are -

- the internationalisation of the Yuan;

- $\quad$ gaining access to natural resources;

- $\quad$ increasing Chinese soft power and goodwill;

- $\quad$ reducing unskilled unemployment in China;

- $\quad$ improving local transportation links; and among others,

- creating an empire.

According to Clover and Hornby, the MSRI is taking shape against the backdrop of a faltering economy and a military rising in strength. ${ }^{51}$ The MSRI, and the BRI at large, is increasingly viewed as a way of defining China's place in the world - which, according to China, is at the centre stage. ${ }^{52}$ Nohara argues that there is more to China's maritime power than material interpretations, such as navies, coastguards and the maritime economy. ${ }^{53}$ Indeed, there are cultural considerations that shape the outlook of nations. As Mahan reminds us, success at sea also depends on the character of the people and the government. ${ }^{54}$

It appears that the revival of the Silk Road is happening simultaneously with the revitalisation of the ancient Chinese philosophy of tianxia, meaning 'all under heaven'. ${ }^{55}$ According to Zhao, the Chinese concept of tianxia is a theory about world politics which was invented about three thousand years ago during the Zhou Dynasty (1046-256 BC). ${ }^{56}$ Tianxia was organised in three concentric circles, with the emperor at the centre, followed by major and minor officials, and finally the fringe 'barbarians' on the outermost circle. From the tianxia perspective, the country at the centre, which is ruled by the emperor, should care about the well-being of others. Furthermore, tianxia has no boundaries and has no self-other division. All are united under the heaven. ${ }^{57}$ The BRI seems to be grounded in the cultural context of tianxia. As Colin Gray points out, all strategic behaviour is cultural behaviour. ${ }^{58}$ For Gray, culture matters because it shapes the process of strategy-making and gives meaning to events. If the MSRI is part of China's grand strategy - as argued by many - then tianxia not only shapes China's strategy-making but also gives meaning to it. 
Along with the tianxia view of the world, is the humiliation narrative that serves as a starting point for how China interacts with other nations. ${ }^{59}$ China stills feel as if its central role in world affairs was weakened by Western incursions that began with the Opium Wars in the $1840 \mathrm{~s} .{ }^{60}$ As China emerges as a global power, many Chinese scholars wonder whether it is now time to promote and construct tianxia, not just for the benefit of China, but also for the whole world. ${ }^{61}$ Therefore, connecting the world through the MSRI and SREB seems very much like a construction of a tianxiaist world system. This system, the argument goes, is vastly different from the Eurocentric view based on imperialism. ${ }^{62}$ In China, there is a growing thirst for Chinese solutions to world problems. ${ }^{63}$ Could the BRI and, more specifically, the MSR, be the vehicle for ushering in the tianxia world view? After all, history has a lot to say about those who became powerful based on what they did at sea.

\section{Sea power as a theoretical lens}

From the very beginning of recorded history, nations have sought to be powerful at sea. ${ }^{64}$ Countries that recognised the value of sea power had and continue to have an economic and strategic advantage over those who do not. ${ }^{65}$ Till defines sea power both as an input and an output. ${ }^{66}$ As an input, sea power includes navies, coastguards and civilian maritime industries. As an output, sea power is more than just what it takes to use the sea. It is also about the ability to influence the behaviour of others based on what one does at sea. Given these definitions, Till arrives at two conclusions about the nature of sea power. First, he concludes that sea power is more than the navy. It also includes the non-military use of the sea, such as merchant shipping, fishing, shipbuilding, and other maritime-related capabilities. Second, Till concludes that sea power is a relative concept. Nearly all countries have some degree of sea power based on their capacity to build ships, their naval strength, their ability to provide seafarers and other means of exploiting the maritime domain. For Till, the real utility of sea power therefore lies in using the sea as an asset for various purposes. ${ }^{67}$

Mahan - a mid-nineteenth and early twentieth century naval theorist - wrote, "whoever rules the waves rules the world". ${ }^{8}$ In his book, The influence of sea power upon history, Mahan argues that the power and prosperity of a nation depend on controlling the world's sea-lanes. His work influenced the naval strategies of many navies around the world. ${ }^{69}$ Even officers of the Imperial Japanese Navy that invaded Pearl Harbour had a copy of Mahan's book on board their ships, ${ }^{70}$ and the book is still read in many naval and military academies around the world. Mahan believed that sea power was a decisive element in determining the course of history. In his book, he refers to how Britain, a small country with almost no natural resources, built the biggest empire in the world on the back of sea power. According to Mahan, the British Empire was founded on sea power, and in turn, sea power was founded on trade. However, Mahan was careful not to present sea power as a standalone element of national power. Instead, he aimed at "putting maritime interests in the foreground without divorcing them from surrounding causes and effects". ${ }^{71}$ 
Mahan's thinking on sea power focuses primarily on the navy. In his book, he recognises that merchant shipping is an essential element of sea power. For him, the history of sea power was mostly a military history, while international politics was all about contestation and, if necessary, the use of force to secure the benefits of sea power for one's own people. While developing his theory of sea power, Mahan emphasised the need for foreign stations or ports for projecting power abroad. Without foreign establishments, Mahan contended, the warships of the United States would be like land birds that are unable to fly too far away from their shores. The need for foreign ports relates to the three requirements Mahan proposes for countries bordering the sea -production, shipping and colonies or markets. At the time of his writing, America had significant surpluses, and Mahan was calling for the country to look outwards for foreign markets. For Mahan, the most crucial national characteristic of sea power is the tendency to trade and the production of something with which to trade. Today, some question the relevance of Mahan's thinking on sea power. Writing on naval warfare specifically, Ian Speller argues that, even though naval tactics change over time, there is much continuity at the strategic and operational levels. ${ }^{72}$ This suggests that Mahan's work might perhaps still be relevant today.

To succeed upon the sea in the twenty-first century, Till offers fours attributes of the sea that a maritime nation must exploit, namely the sea as a resource (as a stock resource), as a medium of transportation (as a flow resource), as a medium of information, and as a medium for dominion. ${ }^{73}$ The navy plays a crucial role in ensuring good order at sea, without which it would be nearly impossible to take full advantage of the four attributes of the sea. It was this very connection between the navy and merchant shipping that Mahan emphasised in his theory of sea power. At the time of Mahan's writing, merchant shipping provided the wealth to the nation, and in turn, the nation protected its merchant ships with the navy. Although times have changed since the days of Mahan, the maritime narrative remains. About 90 per cent of global trade is carried by sea, and recently, there has been talk about the emerging blue economy, which has the potential to transform the economies of many nations. ${ }^{74}$

Many parallels can be drawn between America during the days of Mahan and China today. First, by the late nineteenth century, America had all the characteristics of an empire, including an expanded conception of security and a strong rationale for outward expansion. ${ }^{75}$ Today, China finds itself in the same situation. With over three decades of fast economic growth, China is showing signs of overproduction, economic stagnation and decreasing returns on capital. ${ }^{76}$ With increasing resource demands, China has also expanded its scope of security to include far-flung regions. ${ }^{77}$ Second, because of overproduction in nineteenth-century America, a more substantial interest in shipping appeared. Outwards, expansion by sea became a matter of survival for America during that period. ${ }^{78}$ Today, China is forced to expand both by sea and land to address the crisis of overproduction and to claim its share of international resources. Like America in the late nineteenth century, China's survival hinges on the ability to move goods to and from distant nations. Therefore, the routes to be established for the BRI are like blood vessels that will sustain China's very livelihood. Third, late nineteenth-century America needed foreign markets to consume its surpluses. Likewise, China is building the MSRI and 
the SREB for this very reason. China today is attempting to bring together production, shipping and markets (colonies), which Mahan calls the "three links" of sea power. ${ }^{79}$

What then does China think of its own sea power? How is the view that the rise of China represents a military, economic and ideological threat to the West seen? The Chinese, according to Jian Yang, reject the "China threat theory" ${ }^{80}$ For them, the rise of China is seen in the light of national rejuvenation and the restoration of China's place in the world. China's rise, according to the Chinese, is about getting back what was lost and not about gaining anything new. ${ }^{81}$ If this is indeed how the Chinese interpret their rise in international relations, their conception of sea power must reflect similar characteristics.

\section{Sea power with Chinese characteristics}

Wei and Ahmed argue that China must build sea power with Chinese characteristics. ${ }^{82}$ According to them, the first such characteristic is "big-picture highly centralised strategic planning that aligns with China's national strategy regarding peaceful progress toward a harmonious world and its foreign strategy". ${ }^{83}$ The authors offer more characteristics of Chinese sea power, among which are:

- to embody the core values of socialism with Chinese characteristics;

- to give priority to the maritime economy;

- $\quad$ to emphasise comprehensive security and cooperative security; and

- $\quad$ the limited use of military and paramilitary forces at sea.

Zhang Wenmu, a prominent sea power proponent in China, believes that sea power in the Chinese context is fundamentally different from the Western conception. ${ }^{84}$ In his view, sea power according to Western ideas denotes 'maritime power'. The Chinese conception, however, is about 'maritime rights', which pertain to Chinese sovereignty. For Zhang Wenmu, with sea power, the Chinese do not seek maritime power, much less maritime hegemony, but rather seek their share of sea rights which any country naturally possesses. According to the Chinese version of sea power, 'sea rights' are considered an extension of national sovereignty. Sea power, therefore, is limited to the means for preserving national interests at sea. ${ }^{85}$ In the Chinese version of sea power, Zhang Wenmu explains that the application of naval force cannot exceed China's scope of sea rights. Among these rights are China's territorial claims in the SCS. China, along with several other countries in the region, has laid claims to portions of the SCS, which remain unresolved to this day. For China, its claims in the SCS are historically derived and must be pursued as part of China's maritime rights. ${ }^{86}$ According to Fravel, China has increased its diplomatic, administrative and military efforts since the mid-2000s to deter other nations from laying claims to the SCS. Thus far, though, China's use of its navy in the SCS has been secondary to diplomatic and administrative means. ${ }^{87}$ It remains to be seen how competing sea rights in the SCS are settled in the future. 


\section{The other side of sea power}

The term 'sea power' still evokes militarism, or more specifically navalism. Sea power and navalism have almost been absorbed into one another to mean the same thing. The reality, however, is that sea power has several components that are difficult to tease apart. Iliopoulos reminds us that sea power is also about geography, geopolitics, geostrategy, geo-economics and geo-culture. ${ }^{88}$ Understanding this is critical for loosening sea power from the ontological confines of navalism. By using 'loosening', the author does not intend to conceptualise sea power without the naval element. Rather, the aim is to point to maritime logistics as the under-examined side of sea power. As discussed earlier, Till provides four attributes of the sea, which, when exploited, brings maritime success. ${ }^{89}$ Among these four attributes is the ability to use the sea as a flow resource. Although the MSRI hinges on all four attributes of the sea, the one most relevant to this study was the sea as medium of transportation and exchange. To delve deeper into how maritime logistics functions as power, the author turns to the disciplines of critical logistics and mobility studies. This approach, the author argues, makes up for the lack of theorisation concerning logistical power in traditional sea power theory.

Scholars in critical logistics and mobility studies recognise the military as the progenitors of logistics. ${ }^{90}$ They point out that the success of logistics in the military led to it being transformed into a business science in the years after World War II (WWII). ${ }^{91}$ Following the war, logistics was recognised as the last unexplored frontier for capital accumulation. In the factories, automation and mechanisation were no longer bringing in the desired profits, and firms were forced to look elsewhere to maximise profits. What then followed was a revolution in logistics where the sites of circulation became the new sites of profitability. ${ }^{92}$ The logistics revolution smashed the factory walls and brought together the sites of production and the sites of circulation..$^{93}$ Cowen argues that the logistics revolution was a "leap in the calculation of economic space". ${ }^{44}$ In maritime logistics, cost savings came primarily from reducing time to loading and unloading ships. There were also profits to be made by reducing labour in favour of mechanising ports. As countries embrace transnational trade agreements to accelerate growth, old ports are being modernised and new ones are being constructed. ${ }^{95}$ Indeed, logistical power has become central to national competitiveness. ${ }^{96}$ In a world of hyperconnectivity, those nations better able to move goods in a timely and reliable manner gain a competitive advantage over those without such capabilities. ${ }^{97}$

Neilson provides five theses for understanding logistics as power. ${ }^{98}$ The first is that logistics provides an unexamined background to contemporary capitalist ways of being and knowing. Here he argues that understanding logistics as the unexamined background of capitalism raises many important political questions, among which is the relationship between capitalism and the state. The second thesis he offers is that logistics has begun to lead strategy and tactics. Being fundamentally a military concept, logistics played a decisive role in the unfolding of wars and, ultimately, human history. Third, Neilson contends that logistical power is political power. He argues that understanding logistics as power requires a rethinking of the political. Even if politics is understood within the Clausewitzian framework that revolves around strategy and tactics, logistics, according 
to Neilson, is hidden in the detail. Therefore, to borrow Clausewitz's dictum that "war is simply a continuation of political intercourse, with the addition of other means", ${ }^{9}$ Neilson's third thesis can be summarised as follows: logistics is the continuation of politics by other means. Fourth, logistics negotiates the heterogeneity of global space and time. In other words, logistical power mediates the 'here and there' as well as the 'now and then'. In a logistically globalised world, what happens across the ocean could have instantaneous local effects. The fifth and final thesis is that logistics produces subjectivity. One way by which logistics does this is by replacing logistics workers by automatons that make up the totality of profitability in the circulatory system.

Some of the theses provided by Neilson are directly relevant to the discussion on the MSRI. Among these is the observation that logistical power is political power. If indeed logistics is the continuation of political intercourse with the addition of other means, then China - the world's top trader - holds much political influence in the world. The MSRI, which passes through at least 65 countries and includes more than a third of the world's population, will only increase China's political influence in the world. The other thesis that is of direct relevance to the MSRI is that logistics negotiates global space and time. Space is mediated, for example, through the construction of maritime infrastructure that renders the land-sea divide irrelevant. Maritime infrastructure is central to the goal of seamless trade sought by many nations. With China investing heavily in the construction of maritime infrastructure in countries along the New Silk Road, the goal is to achieve unimpeded trade by making spatial limitations a thing of the past.

Trade data also support the view that China is a logistical empire. By 'logistical empire', the author simply refers to the centrality of commodity flows for China's economy. With over 90 per cent of China's trade by volume flowing by sea, maritime trade remains the primary engine for China's economic growth. ${ }^{100}$ According to trade data from UN Comtrade, China's trade has expanded at a rapid pace over the last two decades. ${ }^{101}$ In 1995, China's total export to the world was valued at US\$ 148.8 billion, with total imports valued at US\$ 132 billion. By 2018, China was exporting over US\$ 2.5 trillion worth of goods while importing US\$ 2.1 trillion. ${ }^{102}$ China's total trade in goods accounted for 12,4 per cent of global trade in 2018 as opposed to 3 per cent in 1995. ${ }^{103}$ For comparative purposes, the United States, which is the second-largest trader, accounted for 11,5 per cent of total global trade in 2018. ${ }^{104}$ Although it is not currently possible to determine with exactitude the value of commodities that will be traded along the proposed New Silk Road, what is clear is that China's political influence will grow proportionally with its logistical power.

However, logistics is not alone in shaping contemporary capitalism. According to Mezzadra and Neilson, finance, extraction and logistics are three economic activities that play a central role in shaping contemporary capitalism. ${ }^{105}$ Thus, analysing these three should allow us to discern the contours of capitalist development. Finance, they argue, permeates the rationality of capitalism as a system, linking processes of control and manipulation to the lives of entire populations. Mezzadra and Neilson define logistics as "the art and science of building networked relations in ways that promote 
transport, communication and economic efficiencies." 106 Extraction provides the raw materials that drive the capitalist engine through means such as land grabbing, mining and other means of appropriating nature. The MSRI seems to be organised around these very principles of finance, extraction and logistics. The connection between these economic activities is so intricate that it is almost impossible to separate them. China-Africa relations exemplify this intricate relationship between finance, extraction and logistics. Even before the MSRI was announced, the Forum on China-Africa Cooperation (FOCAC) had already determined Africa's role as a supplier of natural resources to China in exchange for Chinese assistance in sectors, such as healthcare, agriculture, infrastructure and finance. ${ }^{107}$ The argument is that Africa can transform its resource curse into a tool for economic development. FOCAC, established in 2000 as a win-win approach to economic development between Africa, and China, is therefore complemented and even exceeded by the MSRI. ${ }^{108}$

For China, maritime logistics represents the next frontier of capital accumulation. There is a growing realisation that national competitiveness depends on the seamless mobilisation of goods. ${ }^{109}$ Mobility is key for China to address both its overcapacity problem and to gain access to international resources. With considerable investments spread across the globe, China's conception of security has also expanded. Cowen points out that, if states invest in the seamless flow of goods, they will also invest in securing the conditions that make free flow possible. ${ }^{110}$ There is thus an inescapable link between maritime logistics and maritime security. In addition to China's naval base in Djibouti, some believe that China will establish more bases along the New Silk Road. ${ }^{111}$ This, of course, brings us back to Mahan's thinking about the intricate connection between maritime commerce and the navy.

\section{Protectors of the logistical empire}

One of the first signs that a country has growing maritime interests is the increased spending on maritime defence. Over the past three decades, the Chinese Liberation Army Navy (henceforth referred to as 'the PLAN' or the 'Chinese Navy') grew in numbers and increasingly became more modern and professional, while expanding its scope of operations. ${ }^{112}$ Internationally, China seeks to become an essential player in promoting maritime security. Examples of the PLAN's overseas operations include anti-piracy operations in the Gulf of Aden since 2008. ${ }^{113}$ China is also playing an active security role in the broader Middle East, Africa and the Indian Ocean regions. ${ }^{114}$ In addition to assisting maritime security efforts, China also seeks to build a naval presence in the region to balance the activities of other navies, especially the Indian navy in the Indian Ocean. ${ }^{115}$

Domestically, co-ordination among China's other maritime actors - such as maritime law enforcement agencies, local governments and the maritime militia - has been improving, especially under the Xi Jinping administration. ${ }^{116}$ Some Chinese civilian vessels have also been reported to partake in the enforcement of China's maritime rights in the SCS. This trend of mobilising civilians to defend the country is known as the "people's war at sea". ${ }^{117}$ Thorne and Spevack state that the people's war at sea extends 
beyond just fishermen and trawlers. It suggests that China's entire merchant marine can be used as an extension of military power. Based on these observations, China's maritime interests are growing and the country is taking drastic steps to defend them. ${ }^{118}$

Looking at the initiative from the Chinese perspective, Thorne and Spevack show that the MSRI is principally about China's interests. ${ }^{119}$ Their study looked at the country's port investments abroad and how they are strategically placed to secure China's access to vital sea lines of communication. By using Chinese policy documents, statements by politicians, and the views of Chinese analysts, Thorne and Spevack conclude that the unofficial research on the BRI contradicts the benign narrative of official policy. Ultimately, they argue, Chinese analysts prioritise securing China's core interests over the win-win economic development narrative. The question then is to what extent China is willing and able to enforce its maritime rights through military means.

\section{Conclusion}

The study on which this article reports sought to conceptualise the MSRI through the lens of sea power theory. The question that was being pursued, was how maritime logistics functions as power. Three main points are worth reiterating in terms of how this question was addressed. First, as the backbone of global trade, maritime logistics is intricately connected to the economic success of nations. The ability to move goods across borders is key to the trade opportunities of a country. For China, the MSRI presents an opportunity for economic prosperity by moving raw materials and goods in and out of the country. Second, the MSRI requires the construction of maritime infrastructure in countries along the proposed routes. It was argued that infrastructure renders the antithesis between land and sea irrelevant and thus facilitates the projection of logistical power ashore. If logistical power is political power - as it is understood in critical logistics and mobility studies - then maritime logistics has the potential to shape events on land in profound ways.

Third, even in today's world where the merchant fleet flows relatively unmolested at sea, disruption (which is the Achilles heel of maritime logistics) remains a threat. For this reason, countries build navies and coastguards to protect their maritime interests and vital sea lines of communication. Referring specifically to the PLAN's naval base in Djibouti, it was argued in this study that there is indeed a connection between maritime logistics and the navy and, more specifically, the MSRI and the PLAN. Furthermore, as China moves to a more dominant position in world politics, there is a need for a navy that is strong and large enough to match the great power status of the country.

Based on the points above, it can be concluded that the MSRI is a pursuit of sea power. As discussed above, the MSRI encompasses economic, political and military power. China already dominates in maritime trade, and the MSRI is set to further that dominant role. China is also simultaneously building a blue-water navy that is gaining ever more recognition in global peacekeeping and anti-piracy operations. Therefore, as China looks seaward, the development of the PLAN and the MSRI seem to be in lockstep. Mahan's thinking about sea power remains relevant today. Although his tactics 
may be anachronistic in today's world, there is undoubtedly a sense of continuity in his ideas at the strategic and operational levels. The development direction of China's sea power is testament to Mahan's seemingly timeless outlook that whoever dominates the sea through trade and naval power holds great influence in the world. 


\section{ENDNOTES}

${ }^{1}$ Lungani Hlongwa is a second year $\mathrm{PhD}$ student at the Institute of Social Research and Cultural Studies at National Chiao Tung University in Taiwan. He holds an MSc degree in technology management from Chung Hua University (Taiwan). He obtained a Bachelor of Military Science degree from the Faculty of Military Science of Stellenbosch University in 2013. His doctoral research focuses on China's rise in international politics, with a specific focus on China's maritime ambitions. His interest in maritime matters can be traced back to his time as a South African naval officer, where he served mostly under training capacity.

2 J-MF Blanchard and C Flint. "The geopolitics of China's Maritime Silk Road Initiative". Geopolitics 22/2. 2017. 223-245.

${ }^{3}$ M Kugelman. "Great potential, many pitfalls: Understanding China's Belt and Road Initiative". Asian Affairs 50/2. 2019. 180-186.

${ }^{4}$ Blanchard \& Flint op. cit.

${ }^{5}$ AJ Andrea. "The Silk Road in world history: A review essay". The Asian Review of World Histories 2/1. 2014. 105-127.

${ }^{6}$ Ibid.

${ }^{7}$ Blanchard \& Flint op. cit.

${ }^{8}$ Ž Koboević, Ž Kurtela \& S Vujičić. "Pomorski Put Svile i Kineska Inicijativa 'pojas i Put". Naše More 65/2. 2018. 113-122.

${ }^{9}$ D Thorne \& B Spevack. "Harbored ambitions: How China's port investments are strategically reshaping the Indo-Pacific”. C4ADS. $<$ https://static1.squarespace.com/ static/566ef8b4d8af107232d5358a/t/5ad5e20ef950b777a94b55c3/1523966489456/ Harbored+Ambitions.pdf $>$ Accessed on 22 May 2020.

${ }^{10}$ T Ameyaw-Brobbey. "The Belt and Road Initiative: Debt trap and its implication on international security". Asian Journal of Multidisciplinary Studies 1/2. 73-81. 2018.

${ }^{11}$ Blanchard \& Flint op. cit.

${ }^{12}$ X Zhang. "Chinese capitalism and the Maritime Silk Road: A world-systems perspective". Geopolitics 22/2. 2017. 310-131.

${ }^{13}$ D Styan. "China's Maritime Silk Road and small states: Lessons from the case of Djibouti". Journal of Contemporary China 29/122. 2020. 191-206.

${ }^{14}$ MA Karim. "China's Proposed Maritime Silk Road: Challenges and Opportunities with Special Reference to the Bay of Bengal Region". Pacific Focus 30/3. 2015. 297-319.

${ }^{15}$ AC-H Lim. "Africa and China's 21st Century Maritime Silk Road". The Asia-Pacific Journal 13/11. 2015. 19.

${ }^{16} \mathrm{~S}$ McGlinchey, R Walters \& C Scheinpflug. International relations theory. Bristol: E-International Relations Publishing, 2017.

${ }^{17}$ L Olivier, T Neethling \& F Vreÿ. "Theoretical approaches in international relations: The South African military as a foreign policy instrument". Scientia Militaria 43/2. 2015.

${ }^{18}$ AT Mahan. "The influence of sea power upon history, 1660-1783". The Project Gutenberg eBook 26 September 2004 < http://www.gutenberg.org/files/13529/13529-h/13529-h. $\mathrm{htm}>$ Accessed on 14 November 2020.

${ }^{19} \mathrm{Z}$ Wei \& S Ahmed. "A general review of the history of China's sea-power theory development”. Naval War College Review 68/4. 2018.

${ }^{20} \mathrm{Ibid}$.

${ }^{21}$ Zhang op. cit.

${ }^{22}$ Wei \& Ahmed op. cit.

${ }^{23}$ Ibid.

${ }^{24}$ JR Holmes \& T Yoshihara. "History rhymes: The German precedent for Chinese seapower". Orbis 54/1. 2010. 14-34. 
${ }^{25}$ JR Holmes. "Is Bismarck China's man?” The Diplomat. 19 February 2001. <https:// thediplomat.com/2011/02/is-bismarck-chinas-man/> Accessed on 18 May 2020.

${ }^{26}$ Holmes \& Yoshihara op. cit

${ }^{27} \mathrm{D}$ Cowen. The deadly life of logistics: Mapping violence in global trade. Minneapolis, MN: University of Minnesota Press, 2014.

${ }^{28}$ Blanchard \& Flint op. cit.

${ }^{29} \mathrm{C}$ Clover \& L Hornby. "China's great game: Road to a new empire". Financial Times. 12 October 2015. <https://www.ft.com/content/6e098274-587a-11e5-a28b50226830d644> Accessed on 18 May 2020.

${ }^{30}$ Ibid.

${ }^{31}$ T Sternberg, A Ahearn \& F McConnell. "Central Asian 'characteristics' on China's New Silk Road: The role of landscape and the politics of infrastructure". Land 6/3. 2017. 1-16.

${ }^{32}$ GS Khurana. "China, India and 'Maritime Silk Road': Seeking a confluence". Maritime Affairs: Journal of the National Maritime Foundation of India 11/1. 2015. 19-29.

${ }^{33}$ AC-H Lim. "China's 'Belt and Road' and Southeast Asia: Challenges and prospects". Journal of Southeast Asian Studies 20/1. 2015. 3-15.

${ }^{34}$ A Aneja. "China steps up drive to integrate Africa with Maritime Silk Road". The Hindu. 19 January 2015. <https://www.thehindu.com/news/international/world/china-steps-updrive-to-integrate-africa-with-maritime-silk-road/article6802385.ece > Accessed on 18 May 2020.

${ }^{35}$ Ibid.

${ }^{36} \mathrm{D}$ Brautigam. The dragon's gift: The real story of China in Africa. Oxford: Oxford University Press, 2009.

${ }^{37}$ R Mulwa \& J Mariara. Natural resource curse in Africa: Dutch disease and institutional explanations. AGRODEP working papers. 2016. <http://ebrary.ifpri.org/utils/getfile/ collection/p15738coll2/id/130799/filename/131010.pdf $>$ Accessed on 18 May 2020.

${ }^{38}$ Ibid. p. 1

${ }^{39} \mathrm{Ibid}$.

${ }^{40}$ Styan op. cit.

${ }^{41}$ Ibid.

${ }^{42}$ JP Cabestan. "China's military base in Djibouti: A microcosm of China's growing competition with the United States and new bipolarity". Journal of Contemporary China 29/125. 2019. 731-747.

${ }^{43}$ Ibid.

${ }^{44}$ L Odgaard. "China's policy on development and security in East Africa”. Scientia Militaria 46/2. 2019

${ }^{45}$ V Bhat. "China's mega fortress in Djibouti could be model for its bases in Pakistan". The Print. 27 September 2017. <https://theprint.in/defence/china-mega-fortress-djiboutipakistan/11031/> Accessed on 18 May 2020.

${ }^{46}$ G Till. Seapower: A guide for the twenty-first century. Oxon: Routledge, 2018.

${ }^{47}$ Blanchard \& Flint op. cit.

${ }^{48}$ Clover \& Hornby op. cit.

${ }^{49}$ Khurana op. cit.

${ }^{50}$ Sternberg et al. op. cit.

${ }^{51}$ Clover \& Hornby op. cit.

${ }^{52}$ Ibid.

${ }^{53}$ JJ Nohara. "Sea power as a dominant paradigm: The rise of China's new strategic identity". Journal of Contemporary East Asia Studies 6/2. 2017. 210-232.

${ }^{54}$ Mahan op. cit. 
${ }^{55}$ N. Noesselt “One Belt, One Road: A New Roadmap for a Sinocentric World?". The Asan

Forum. 2016. < http://www.theasanforum.org/one-belt-one-road-a-new-roadmap-fora-sinocentric-world/> Accessed on November 142020.

${ }^{56}$ T Zhao. Redefining A Philosophy for World Governance. Singapore: Springer, 2019.

${ }^{57} \mathrm{R}$ Yang. "The concept of Tianxia and its impact on Chinese discourses on the West". In C Halse (ed), Asia Literate Schooling in the Asian Century. Routledge, 2015. <http:// hub.hku.hk/handle/10722/201975> Accessed on 20 May 2020.

${ }^{58}$ CS Gray. Modern strategy. New York, NY: Oxford University Press, 1999.

${ }^{59} \mathrm{M}$ Varrall. "Chinese worldviews and China's foreign policy". Lowy Institute. 26 September 2015. <https://www.lowyinstitute.org/publications/chinese-worldviews-and-china-sforeign-policy $>$ Accessed on 20 May 2020.

${ }^{60}$ Ibid.

${ }^{61}$ M Puranen. ““"All Under Heaven as one Family”: Tianxiaist Ideology and the emerging Chinese Great Power Identity”. Journal of China and International Relations 7/1. 2019. 44-61.

${ }^{62}$ Ibid.

${ }^{63}$ Ibid.

${ }^{64}$ Till op. cit.

${ }^{65}$ Ibid.

${ }^{66} \mathrm{Ibid}$.

${ }^{67}$ Ibid.

${ }^{68}$ Mahan op. cit.

${ }^{69} \mathrm{RD}$ Parker. "Mahan for the twenty first century: His principles still apply to national power".

Defence Technical Information Center. 2003. $<$ https://apps.dtic.mil/docs/citations/ ADA526258> Accessed on 20 May 2020.

${ }^{70} \mathrm{~J}$ Smith. "The influence of Alfred Thayer Mahan upon the Imperial Japanese Navy". Norwich University. 2013. <https://www.researchgate.net/publication/271644766_The Influence_of_Alfred_Thayer_Mahan_upon_the_Imperial_Japanese_Navy $>$ Accessed on 20 May 2020 .

${ }^{71}$ Mahan op. cit.

${ }^{72}$ D Jordan, J Kiras, D Lonsdale, I Speller, C Tuck, \& C Walton. Understanding modern warfare. Cambridge: Cambridge University Press, 2008, 122-179.

${ }^{73}$ Till op. cit.

${ }^{74}$ T Potgieter. "Oceans economy, blue economy, and security: notes on the South African potential and developments". Journal of the Indian Ocean Region 14/1. 2017. 49-70.

${ }^{75}$ JW Meiser. Power and restraint: The rise of the United States, 1898-1941. Washington, DC: Georgetown University Press, 2015.

${ }^{76}$ Zhang op. cit.

${ }^{77}$ Z Wenmu. "Sea power and China's strategic choices". World Security Institute. 2006. <https:// www.issuelab.org/resources/372/372.pdf> Accessed on 20 May 2020.

${ }^{78}$ Mahan op. cit.

${ }^{79}$ Ibid. p. 28

${ }^{80} \mathrm{~J}$ Yang. "The rise of China: Chinese perspective". In JC Cooney (ed), The rise of China and international security. London: Routledge, 2008, 13-37.

${ }^{81}$ Ibid.

${ }^{82}$ Wei \& Ahmed op. cit.

${ }^{83}$ Ibid. p.92

${ }^{84}$ Wenmu op. cit.

${ }^{85}$ Ibid.

${ }^{86}$ M Taylor Fravel. "China's strategy in the South China Sea". Contemporary Southeast Asia 33/3. 2011. 292. 
${ }^{87}$ Ibid.

${ }^{88}$ I Iliopoulos. "Strategy and geopolitics of sea power throughout history". Baltic Security \& Defence Review 11/2. 2009.

${ }^{89}$ Till op. cit.

${ }^{90}$ D Cowen. "A geography of logistics: Market authority and the security of supply chains." Annals of the Association of American Geographers, 100/3. 2010. 600-620.

${ }^{91}$ Cowen op. cit.

${ }^{92}$ C Martin. Shipping container. London: Bloomsbury, 2016.

${ }^{93}$ B Neilson. "Five theses on understanding logistics as power". Distinktion: Journal of Social Theory 13/3. 2012. 322-339.

${ }^{94}$ Cowen op. cit. p. 25

${ }^{95} \mathrm{C}$ Zheng, Z Xiao, W Zhou, X Chen \& X Chen. 21st century Maritime Silk Road: A peaceful way forward. Singapore: Springer, 2018.

${ }^{96}$ Cowen op. cit.

${ }^{97}$ Ibid.

${ }^{98}$ Neilson op. cit.

${ }^{99} \mathrm{C}$ von Clausewitz. On War. Princeton, New Jersey: Princeton University Press, 1976. p. 605

${ }^{100}$ R Ghiasy, F Su \& L Saalman. "The twenty-first century Maritime Silk Road: Security implications and ways forward for the European Union". SIPRI. September 2018. $<$ https://www.sipri.org/publications/2018/other-publications/twenty-first-centurymaritime-silk-road-security-implications-and-ways-forward-european-union> Accessed on 22 May 2020.

${ }^{101}$ UN Comtrade. "Download trade data: International trade statistics". $<$ https://comtrade.un.org/data/> Accessed on 18 May 2020.

102 Ibid.

${ }^{103}$ Ibid.

104 Ibid.

${ }^{105}$ S Mezzadra \& B Neilson. "Extraction, logistics, finance: Global crisis and the politics of operations". Radical Philosophy 173/1. 2013. 8-18.

${ }^{106}$ Ibid. p. 12

${ }^{107}$ Z Aiping \& S Zhan. "Origin, achievements, and prospects of the Forum on China-Africa Cooperation". China International Studies. N.d. $<$ https://www.focac.org/eng/lhyj_1/ yjcg/P020181026382446204313.pdf $>$ Accessed on 22 May 2020

${ }^{108} \mathrm{~K}$ King. "China-Africa education cooperation: From FOCAC to Belt and Road". ECNU Review of Education 3/2. 2019. 221-234.

${ }^{109}$ Cowen op. cit.

${ }^{110}$ Ibid.

${ }^{111}$ Cabestan op. cit.

${ }^{112}$ Nohara op. cit.

${ }^{113}$ CD Yung \& R Rustici. China strategic perspectives. NDU Press. 2014. $<$ https://ndupress.ndu.edu/Portals/68/Documents/stratperspective/china/ ChinaPerspectives-7.pdf $>$ Accessed on 22 May 2020.

${ }^{114}$ Cabestan op. cit.

${ }^{115}$ Ibid.

116 Thorne \& Spevack op. cit.

${ }^{117}$ Ibid.

${ }^{118}$ Ibid.

${ }^{119}$ Ibid. 